PNL-2822

UC-70

\title{
Depleted Uranium Valuation
}

\author{
M. A. Lewallen \\ M. K. White \\ U. P. Jenquin
}

April 1979

Prepared for the U.S. Department of Energy under Contract EY-76-C-06-1830

Pacific Northwest Laboratory Operated for the U.S. Department of Energy by Battelle Memorial Institute 
NOTICE

This report was prepared as an account of work sponsored by the United States Government. Neither the United States nor the Department of Energy, nor any of their employees, nor any of their contractors, subcontractors, or their employees, makes any warranty, express or implied, or assumes any legal liability or responsibility for the accuracy, completeness or usefulness of any information, apparatus, product or process disclosed, or represents that its use would not infringe privately owned rights.

The views, opinions and conclusions contained in this report are those of the contractor and do not necessarily represent those of the United States Government or the United States Department of Energy.

\author{
PACIFIC NORTHWEST LABORATORY \\ operated by \\ BATTELLE \\ for the \\ UNITED STATES DEPARTMENT OF ENERGY \\ Under Contract EY-76-C-06-1830
}

Printed in the United States of Am
Available from
National Technical Information Ser
United States Department of Comm
5285 Port Royal Road
Springfield, Virginia 22151
Price: Printed Copy S_*; Microfich




\title{
33679000493793
}

\section{DEPLETED URANIUM VALUATION}

\author{
M. A. Lewallen \\ M. K. White \\ $U$. P. Jenquin
}

Apri1 1979

Prepared for

the U.S. Department of Energy

Under Contract EY-76-C-06-1830

Pacific Northwest Laboratory Richland, Washington 99352 


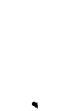




\section{CONTENTS}

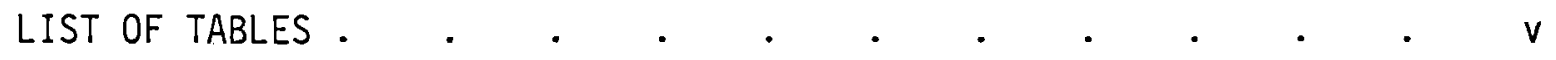

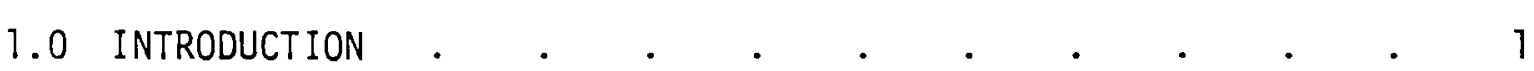

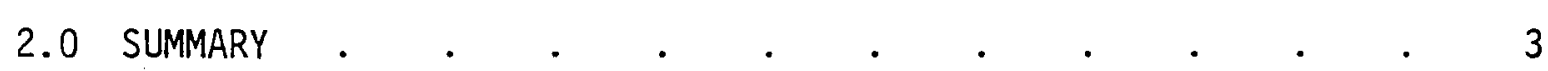

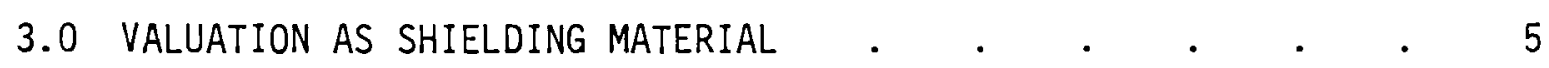

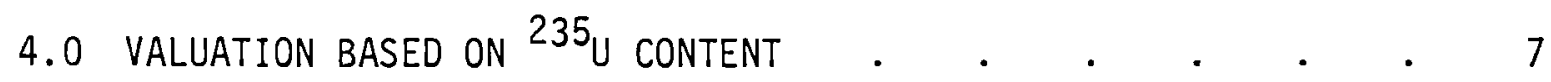

4.1 ENRICHMENT FEED MATERIAL - GASEOUS DIFFUSION

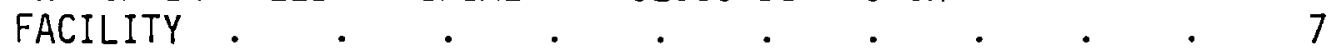

4.2 ENRICHMENT FEED MATERIAL - ADVANCED CONCEPT

FACILITY $\quad . \quad \cdot \quad \cdot \quad \cdot \quad \cdot \quad \cdot \quad \cdot \quad \cdot \quad \cdot \quad 8$

5.0 VALUATION AS MOX DILUENT AND BLANKET MATERIAL. . . . . 13

6.0 VALUATION COMPARED TO ALTERNATIVE FERTILE MATERIAL-
THORIUM

7.0 REFERENCES. $\quad . \quad$.

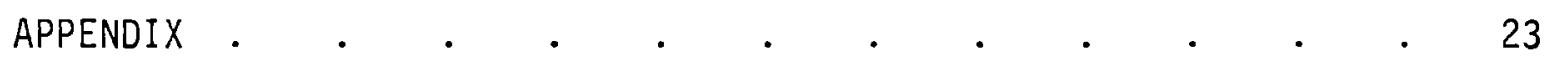





\section{TABLES}

2.1 Estimated Depleted Uranjum Value, $\$ / \mathrm{kg} U$ Chemical Form:

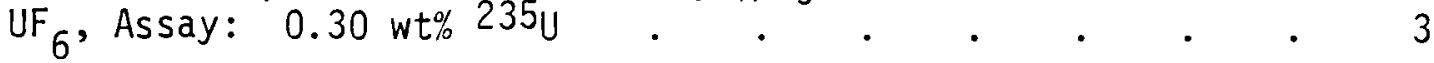

4.1 Depleted Uranium Valued as Feed Material - Gaseous

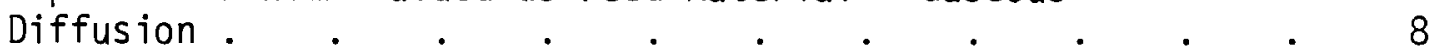

5.1 Annual Mass Flows for MOx LMFBR Core + Axial Blanket

and Radial Blanket, $\mathrm{kg}$. $\quad . \quad . \quad . \quad . \quad . \quad . \quad 13$

5.2 Calculated Coefficients for $a$ and $b$ in the Equation

$" T(\$ / \mathrm{kg})=\mathrm{a}+\mathrm{bA} "$. $. \quad . \quad . \quad . \quad . \quad . \quad . \quad 15$

6.1 Steady State Mass Flows for Depleted Uranium Radial

Blanket Design, $\mathrm{kg} \mathrm{HM/Year} . \quad . \quad . \quad . \quad . \quad . \quad 18$

6.2 Steady State Mass Flows Thorium Blanket Design,

$\$ / \mathrm{kg}$ HM Design, $\mathrm{kg} \mathrm{HM/Year} . \quad . \quad . \quad . \quad . \quad . \quad . \quad 18$

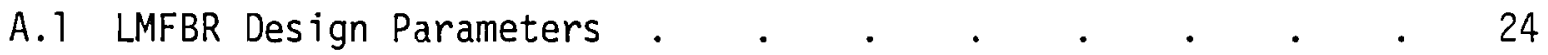

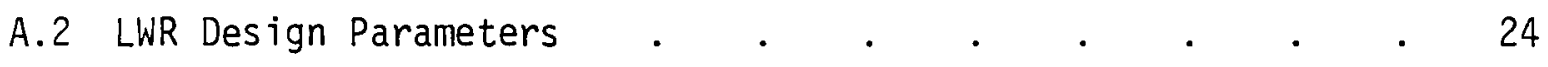

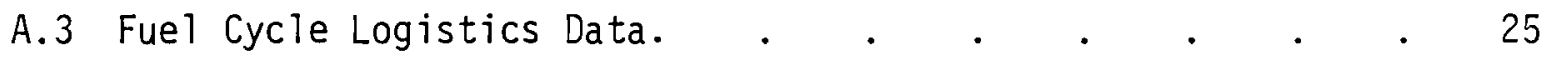

A.4 Fuel Cycle Unit Costs (1978 Dollars) . . . . . . . 25

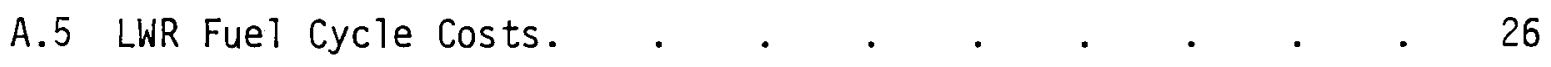

A.6 LWR Fissile Material Indifference Prices for Natural

A.7 LMFBR Fuel Cycle Costs as a Function of Tails Assay . . 27

A.8 LMFBR Fuel Cycle Costs as a Function of "a" and "b" . . 27

A.9 Indifference Cost Equation as a Function of "a" and "b". . 28

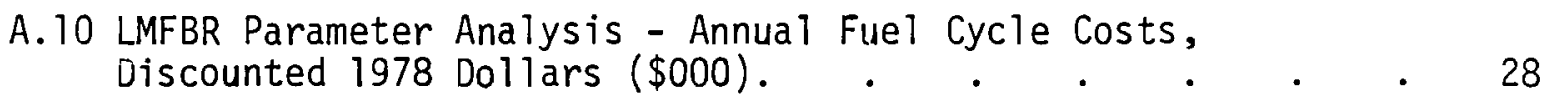

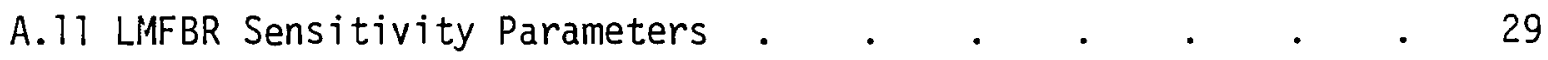

A.12 LMFBR Annual Fuel Cycle Cost Equations . $\quad . \quad$ • . . . 29

A.13 LMFBR Tails Valuation - Comparison With Thorium . . . 30 
.

. 


\subsection{INTRODUCTION}

In order to use natural uranium to fuel existing commercial Light Water Reactor (LWR) power plants, the uranium must be processed to enrich its ${ }^{235_{U}}$ content. In the enrichment process, natural uranium is fed to the plant, enriched uranium is produced and the residual depleted uranium (called the tails) is recovered and stored in anticipation of future use. The future uses include: production of plutonium to fuel new power plants (e.g., fast breeder reactors), feed for advanced process enrichment plants, and material for radiation shields.

Current markets for depleted uranium are limited. The future markets are subject to large technological and political uncertainties. Thus, accurately computing a value for depleted uranium is a difficult exercise. A complete analysis of the value of depleted uranium should include: 1) computing a value for depleted uranium in each of its potential uses; 2) estimating the probability of occurrence and period of these future applications; and 3) appropriately weighting the computed values with the estimated probabilities and periods of occurrence. This analysis will focus on the valuation step (as in one above) for several postulated scenarios where depleted uranium could have value.

The implicit value of depleted uranium is derived from the following characteristics:

- The large density of uranium (especially for shielding or ammunition applications).

- The residual quantities of ${ }^{235} U$ contained in depleted uranium.

- The fertile material, ${ }^{238} \mathrm{U}$, present.

This analysis postulates employing these attributes in various ways to compute the value of depleted uranium. 
.

,

- 


\subsection{SUMMARY}

The following uses for depleted uranium were examined to determine its value:

- A substitute for lead in shielding applications.

- Feed material in gaseous diffusion enrichment facilities.

- Feed material for an advanced enrichment concept.

- Mixed Oxide (MOX) diluent and blanket material in liquid metal fast breeder reactors (LMFBR).

- Fertile material in LMFBR systems.

A range of depleted uranium values was calculated for each' of these applications. The sensitivity of these values to analysis assumptions will be discussed in the remainder of the report. The calculated range of depleted uranium values is listed in Table 2.1.

TABLE 2.1. Estimated Depleted Uranium Value, $\$ / \mathrm{kg} U$ Chemical Form: $U F_{6}$, Assay: 0.30 wt\% $235 \mathrm{U}$

\begin{tabular}{|c|c|c|c|}
\hline Scenario & $\begin{array}{l}\text { Tails Value } R \\
\text { Lower Bound } \\
\end{array}$ & $\frac{\text { ge, } \$ / \mathrm{kg} \mathrm{U}}{\text { Upper Bound }}$ & Comments \\
\hline Shielding Material & $\begin{array}{l}\text { (Present Value } \\
\text { Storage Costs) }\end{array}$ & u] & Substitute for lead \\
\hline $\begin{array}{l}\text { Gaseous Diffusion } \\
\text { Feed Material }\end{array}$ & $\begin{array}{l}\text { (Present Value } \\
\text { Storage Costs) }\end{array}$ & 18 & $\begin{array}{l}\text { For variable cost } \\
\text { recovery at optimum } \\
\text { tails }\end{array}$ \\
\hline $\begin{array}{l}\text { Advanced Concept } \\
\text { Feed Material }\end{array}$ & -- & 47 & Maximum value \\
\hline $\begin{array}{l}\text { MOx Diluent } \\
\text { in LMFBR }\end{array}$ & -- & 78 & $\begin{array}{l}\text { Threshold } 238 U \text { plus } \\
\text { linear } 235 U \text { contribution }\end{array}$ \\
\hline $\begin{array}{l}\text { Fertile Material } \\
\text { in LMFBR Systems }\end{array}$ & 38 & -- & $\begin{array}{l}\text { Corresponds to estimate } \\
\text { of thorium price }\end{array}$ \\
\hline
\end{tabular}


These values are reported in constant 1978 dollars. The first two scenarios represent currently achievable applications for depleted uranium. For these two cases the lower bound for tails value is the negative of the present value of all future storage costs. This represents a dollar value outlay in 1978 that equals the sum of all discounted future storage charges.

The final three price ranges reported in Table 2.1 represent potential applications for depleted uranium. To meaningfully compare the depleted uranium value for these three applications to that for the first two would require estimating their probabilities and time of their occurrence. 


\subsection{VALUATION AS SHIELDING MATERIAL}

Depleted uranium has occasionally been used as a shielding material. In certain applications, where weight considerations are important, depleted uranium has been used as a replacement for lead to maintain adequate shielding properties while concurrently reducing weight. Oak Ridge National Laboratory has designed and built casks with depleted uranium. More recently General Electric used depleted uranium in the construction of their IF-300 spent fuel shipping cask. For these applications depleted uranium is superior to lead from a weight-shielding standpoint but more difficult to fabricate. Because of this trade-off, it can be postulated that the approximate value of depleted uranium is that of lead. Since lead is currently priced at $\$ 0.39 / 1 \mathrm{~b}$ or $\$ 0.86 / \mathrm{kg},(1)$ the approximate value of depleted uranium for shielding applications is $\$ 1 / \mathrm{kg}$. 


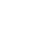




\subsection{VALUATION BASED ON $235 \mathrm{U}$ CONTENT}

Depleted uranium contains varying amounts of $235 \mathrm{U}$. The Department of Energy is currently storing approximately 250 thousand metric tons of depleted uranium. Of this, $14 \%$ is at an assay $0.30 \mathrm{wt} \%{ }^{235} \mathrm{U}, 31 \%$ at $0.25 \mathrm{wt} \%{ }^{235} \mathrm{U}$, and $55 \%$ at $0.20 \mathrm{wt} \%{ }^{235} \mathrm{U}$. At present the enrichment cascade is operating at a tails assay of $0.20 \mathrm{wt} \%{ }^{235} \mathrm{U}$ and will produce about 20 thousand metric tons of tails annually.

\subsection{ENRICHMENT FEED MATERIAL - GASEOUS DIFFUSION FACILITY}

The value of depleted uranium can be estimated by assuming its use as feed material to produce natural uranium. A price for the depleted uranium can be estimated for which a utility would be indifferent to using this process to obtain natural uranium or purchasing the natural uranium directly. This relationship can be formulated as:

$$
P=W_{Q} \cdot W_{P}+U_{Q} \cdot U_{P}
$$

where

$P$ is the price of natural uranium as $U F_{6}, \$ / k g \cup$ (product)

$W_{0}$ is the quantity of depleted uranium fed to cascade per $\mathrm{kg}$

of product, $\mathrm{kg} U$ (feed) $/ \mathrm{kg} \cup$ (product)

$W_{p}$ is the price of depleted uranium as $U_{6}, \$ / k g U$ (feed)

$U_{Q}$, is the quantity of separative work required per $\mathrm{kg}$ of product, SWU/kg U (product)

$U_{p}$ is the price of separative work, \$/SWU

Solving for $w_{p}$, the tails indifference price, yields:

$$
W_{P}=\frac{P-U_{Q} \cdot U_{P}}{W_{Q}}
$$

Table 4.1 shows resultant prices of tails for various combinations of $P$, $U_{Q}, U_{P}$, and $W_{Q}$. Several tails assays as well as two different SWU prices were considered. These analyses resulted in a range of indifference values for depleted uranium of $\$ 2.97$ to $\$ 17.65 / \mathrm{kg}$ uranium. 
TABLE 4.1. Depleted Uranium Valued as Feed Material - Gaseous Diffusion

\begin{tabular}{|c|c|c|c|c|c|c|c|}
\hline $\begin{array}{l}\text { Feed Assay } \\
w t^{\circ} 235 \mathrm{U}\end{array}$ & $\begin{array}{r}\text { Tails a) } \\
\text { Assay, } \\
\text { wt:\% } 23 s_{U} \\
\end{array}$ & $\begin{array}{c}\text { Natural } \\
\text { Uranium } \\
\text { Value, } \$ / \mathrm{kg} U \\
\end{array}$ & $\begin{array}{c}\text { Separative } \\
\text { Work Price } \\
5 / 5 W U \\
\end{array}$ & $\begin{array}{c}\begin{array}{c}\text { Separative } \\
\text { Work }\end{array} \\
\text { Requirements, SWU }\end{array}$ & $\begin{array}{c}\text { Feed } \\
\text { Requirements } \\
\mathrm{kg} \mathrm{U} \\
\end{array}$ & Comments & $\begin{array}{l}\text { Depleted Uranium } \\
\text { Value, } \$ / \mathrm{kg} \\
\end{array}$ \\
\hline 0.30 & 0.20 & 118 & 86 & 0.806 & 5.10 & Current market conditions & 9.55 \\
\hline 0.30 & 0.14 & 118 & $53^{b)}$ & 1.10 & 3.57 & $\begin{array}{l}\text { Sid price at estimated } \\
\text { marginal cost }\end{array}$ & 17.65 \\
\hline 0.25 & 0.20 & 118 & 86 & 1.02 & 10.2 & $\begin{array}{l}\text { Current market con- } \\
\text { ditions }\end{array}$ & 2.97 \\
\hline 0.25 & 0.14 & 118 & $50^{b)}$ & 1.39 & 5.18 & $\begin{array}{l}\text { SwU price at estimated } \\
\text { marginal cost }\end{array}$ & 9.36 \\
\hline 0.20 & 0.14 & 118 & $50^{b)}$ & 1.78 & 9.52 & $\begin{array}{l}\text { SWU price at estimated } \\
\text { marginal cost }\end{array}$ & 3.05 \\
\hline
\end{tabular}

a) The value of this tails stream is assumed to be zero.

b) This is an estimate of the marginal cost of a SWU. This

value represents the variable operating cost for an

incremental unit of enrichment service.

\subsection{ENRICHMENT FEED MATERIAL - ADVANCED CONCEPT FACILITY}

The value of depleted uranium as feed material to an advanced enrichment concept could differ from its value as feed to current enrichment processes. Production of typical light water reactor (LWR) fuel is represented as foliows:

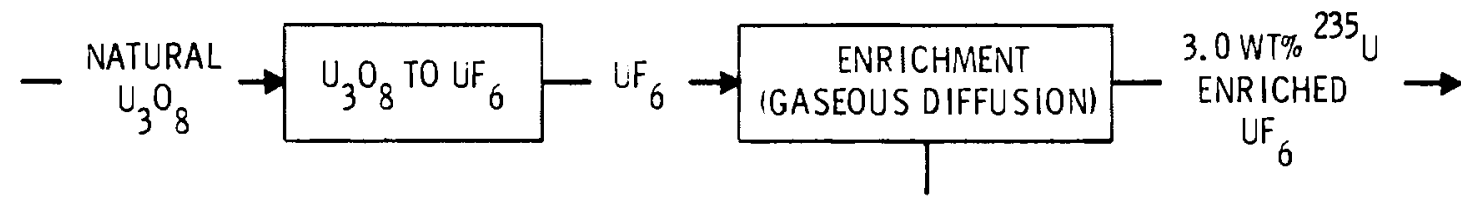

$$
\begin{aligned}
& \text { UF }_{6} \text { TAILS } \\
& \text { @ } \\
& 0.20 \mathrm{WT}^{235} \mathrm{U}
\end{aligned}
$$

The cost of this product as $\mathrm{UF}_{6}$ can be expressed as:

$$
V_{P}=F_{Q} \cdot F_{P}+C_{Q} \cdot C_{P}+U_{Q} \cdot U_{P}
$$

where the variables and representative vaiues are defined as follows:

$V_{p}$ is the cost of $3.0 \mathrm{wt} \% 23 \mathrm{U}_{\mathrm{U}}$ as $U F_{6}, \$(\mathrm{~kg} U$ product)

$F_{Q}$ is the quantity of natural uranium required per $\mathrm{kg}$ of product, $5.48 \mathrm{~kg}$ 'J (feed) $/ \mathrm{kg} \cup$ (product) 
$F_{p}$ is the price of natural uranium as $U_{3} O_{8}, \$ 113 / \mathrm{kg} \cup$ (feed)

$C_{Q}$ is the quantity of converted natural uranium,

$5.48 \mathrm{~kg} \mathrm{U}$ (feed) $/ \mathrm{kg} \mathrm{U}$ (product)

$C_{p}$ is the price of conversion operation, $\$ 5.00 / \mathrm{kg} \mathrm{U}$ (feed)

$U_{0}$ is the separative work per $\mathrm{kg} U$ of product, $4.306 \mathrm{SWU} / \mathrm{kg} \cup$ (product)

$U_{p}$ is the separative work price, $\$ 86 /$ SWU.

Substituting into (3) yields:

$V_{p}=5.48 \cdot 113+5.48 \cdot 5+4.306 \cdot 86$

$V_{p}=\$ 1017$ per $\mathrm{kg}$ uranium (product)

An advanced enrichment concept, if it were to be competitive, would require providing $U_{6}$ at $3.0 \mathrm{wt} \%{ }^{235} U$ for no more than the above cost. A hypothetical flow diagram for such a concept is shown below.

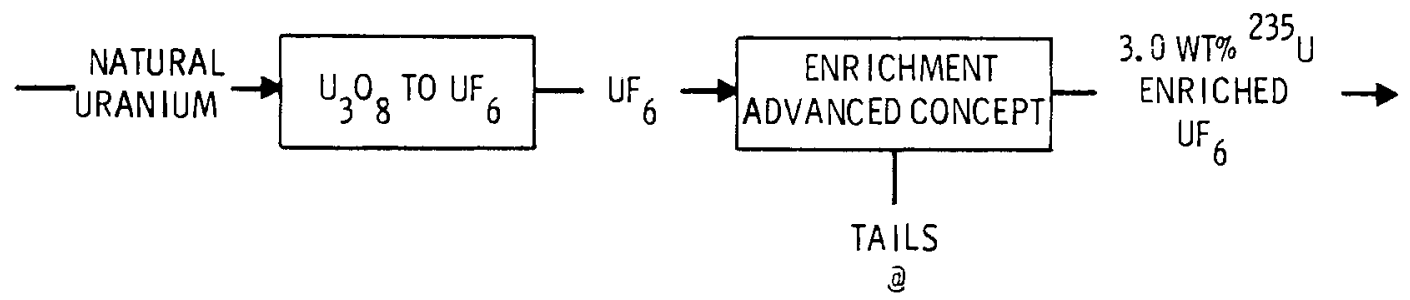

0.08 WT\% ${ }^{235} \mathrm{U}$

The product cost for this process (as $U F_{6}$ ) can be expressed as:

$$
V_{P}=F_{Q} \cdot F_{P}+C_{Q} \cdot C_{P}+E
$$

where

$E$ is the enrichment charge, $\$ / \mathrm{kg} U$ (product)

$F_{Q}$ is the quantity of natural uranium required per $\mathrm{kg}$ of product, $4.63 \mathrm{~kg} \mathrm{U}$ (feed) $/ \mathrm{kg} \cup$ (product) 
$F_{p}$ is the price of natural uranium as $U_{3} 0_{8}, \$ 113 / \mathrm{kg} \mathrm{U}$ (feed)

$C_{Q}$ is the quantity of converted natural uranium, $4.63 \mathrm{~kg} \mathrm{U}$ (feed) $/ \mathrm{kg} \cup$ (product)

$C_{p}$ is the price of conversion operation, $\$ 5 / \mathrm{kg} U$ (feed)

$V_{p}$ is the value of $3.0 \mathrm{wt} \%{ }^{235} U$ as $U F_{6}, \$ 1017$ per $\mathrm{kg} \mathrm{U}$ (product)

Thus solving for $E$ and substituting yields:

$$
E=V_{P}-F_{Q} \cdot F_{P}-C_{Q} \cdot C_{P}=\$ 471 \text { per } \mathrm{kg} \text { uranium product. }
$$

If it is assumed that for the hypothetical advanced concept, the enrichment charge is relatively indifferent to the quantity of feed material processed ${ }^{(a)}$, a value for tails can be calculated. The system flow diagram for this calculation is shown below:

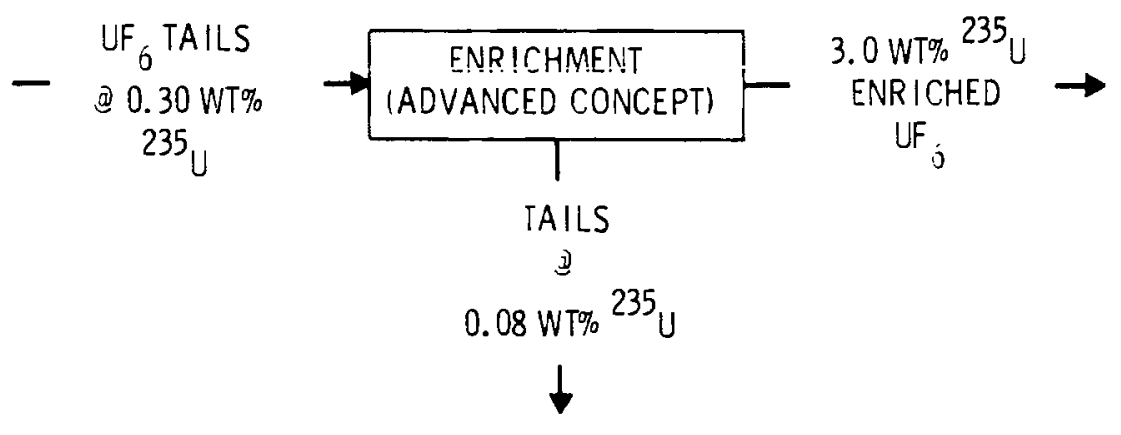

Reformulating equation (2) for this process yields:

$V_{P}=W_{Q} \cdot W_{P}+E$

(a) This is equivalent to assuming the cost of the process is more dependent on the amount of $235 \mathrm{U}$ removed than the amount of material processed. 
where

$W_{Q}$ is the quantity of depleted uranium fed to enrichment process, $\mathrm{kg} \cup$ (feed) $/ \mathrm{kg} \cup$ (product)

$W_{p}$ is the price of depleted uranium as $U_{6}, \$ / k g \cup$ (feed)

$E$ is the Enrichment Change, $\$ 471 / \mathrm{kg} \mathrm{U}$ (product)

$W_{Q}$ for this case (assuming $0.30 \mathrm{wt} \%{ }^{235} \mathrm{U}$ ) is $13.3 \mathrm{~kg}$ tails per $\mathrm{kg}$ product, and $U_{p}$ is $\$ 1017 / \mathrm{kg}$ as previously caiculated. Substituting into (4) and solving for $W_{p}$ yields:

$$
W_{P}=\frac{V_{P}-E}{W_{Q}}=\$ 41 \text { per } \mathrm{kg} \text { uranium (feed) }
$$

This is the maximum that $0.3 \mathrm{wt} \%{ }^{235} \mathrm{UF}_{6}$ material could be valued at for this hypothetical advanced enrichment concept. Tails with lower ${ }^{235} U$ assay would have less value. 


\subsection{VALUATION AS MOX DILUENT AND BLANKET MATERIAL}

Depleted uranium may be used as the diluent in mixed oxide cores and as the fertile material in the blanket regions of LMFBRs. The residual quantities of ${ }^{235} \mathrm{U}$ in depleted uranium represent fissile material, which reduces plutonium charge requirements. As the ${ }^{235} \mathrm{U}$ assay increases the plutonium requirement decreases. The ${ }^{238} \mathrm{U}$ in depleted uranium is a fertile material which absorbs a neutron to produce additional plutonium.

Both of these properties impart value to depleted uranium. Calculations to determine the value of depleted uranium for this application were made based on a conceptual LMFBR system. $(2,3,4)$ These calculations compare the required plutonium charge enrichment for several different assays of ${ }^{235} U$ in depleted uranium diluent. The resultant mass flows are shown in Table 5.1. Figure 5.1 shows the relationship between assay and charge enrichment.

TABLE 5.1. Annual Mass Flows for MOx LMFBR Core + Axial Blanket and Radial Blanket, $\mathrm{kg}$

\begin{tabular}{|c|c|c|c|c|c|c|c|c|c|c|c|}
\hline \multirow{3}{*}{ Charge } & Isotope & $\begin{array}{l}0.0 \mathrm{wt} \% \\
\text { Core } \\
\end{array}$ & $\begin{array}{r}235 \mathrm{~J} \\
\text { Radial } \\
\end{array}$ & $\begin{array}{l}0.2 \text { wt\% } \\
\text { Core }\end{array}$ & $\begin{array}{r}235 \mathrm{U} \\
\text { Radial } \\
\end{array}$ & $\begin{array}{l}0.3 \mathrm{wt} \% \\
\text { Core }\end{array}$ & $\begin{array}{r}235 \mathrm{U} \\
\text { Radial } \\
\end{array}$ & $\begin{array}{l}0.5 \mathrm{wt} \% \\
\text { Core } \\
\end{array}$ & $\begin{array}{r}235 \mathrm{u} \\
\text { Radial } \\
\end{array}$ & \multicolumn{2}{|c|}{$\begin{array}{r}\text { Natural } \frac{1}{5} \\
(.711 \text { wt\% } 235 \mathrm{~J}) \\
\text { Core Radial }\end{array}$} \\
\hline & U-235 &.-- & 9256 & 52 & 19 & 78 & 28 & 130 & 46 & 185 & 66 \\
\hline & U-238 & 25848 & 9256 & 25831 & 9237 & 25822 & 9228 & 25807 & 9210 & 25789 & 9189 \\
\hline \multicolumn{2}{|c|}{ Total U } & 25848 & 9256 & 25883 & 9256 & 25900 & 9256 & 25937 & 9256 & 25974 & 9255 \\
\hline \multirow{5}{*}{\multicolumn{2}{|c|}{$\begin{array}{r}P u-239 \\
P u-240 \\
P u-241 \\
P u-242 \\
\text { Total } \mathrm{Pu}\end{array}$}} & 1558 & -- & 1536 & -- & 1526 & -- & 1504 & -- & 1482 & -- \\
\hline & & 679 & -- & 670 & -- & 666 & -- & 656 & -- & 646 & -- \\
\hline & & 323 & -- & 318 & -- & 316 & -- & 312 & -- & 307 & -- \\
\hline & & 85 & -- & 84 & -- & 83 & -- & 82 & -- & 80 & -- \\
\hline & & 2645 & -- & 2608 & -- & 2591 & -- & 2554 & -- & 2515 & -- \\
\hline \multicolumn{2}{|c|}{ Total } & 28493 & 9256 & 28491 & 9256 & 28491 & 9256 & 28491 & 9256 & 28489 & 9255 \\
\hline \multirow[t]{9}{*}{ Discharge } & U-235 & -- & -- & 33 & 15 & 50 & 23 & 84 & 38 & 119 & 54 \\
\hline & U-238 & 24374 & 9060 & 24365 & 9041 & 24361 & 9032 & 24354 & 9015 & 24345 & 8994 \\
\hline & 10 & 24374 & 9060 & 24398 & 9056 & 24411 & 9055 & 24438 & 9053 & 24464 & 9048 \\
\hline & Pu-239 & 1884 & 171 & 1871 & 170 & 1864 & 170 & 1851 & 169 & 1837 & 169 \\
\hline & Pu-240 & 751 & 5 & 741 & 5 & 736 & 5 & 726 & 5 & 715 & 5 \\
\hline & Pu-241 & 204 & 0 & 202 & 0 & 200 & 0 & 198 & 0 & 187 & 0 \\
\hline & Pu-242 & 100 & 0 & 99 & 0 & 98 & 0 & 97 & 0 & 95 & 0 \\
\hline & $1 \mathrm{Pu}$ & 2939 & 176 & 2913 & 175 & 2898 & 175 & 2872 & 174 & 2834 & 174 \\
\hline & & 27313 & 9236 & 27311 & 9231 & 27309 & 9230 & 27310 & 9227 & 27298 & 9222 \\
\hline
\end{tabular}




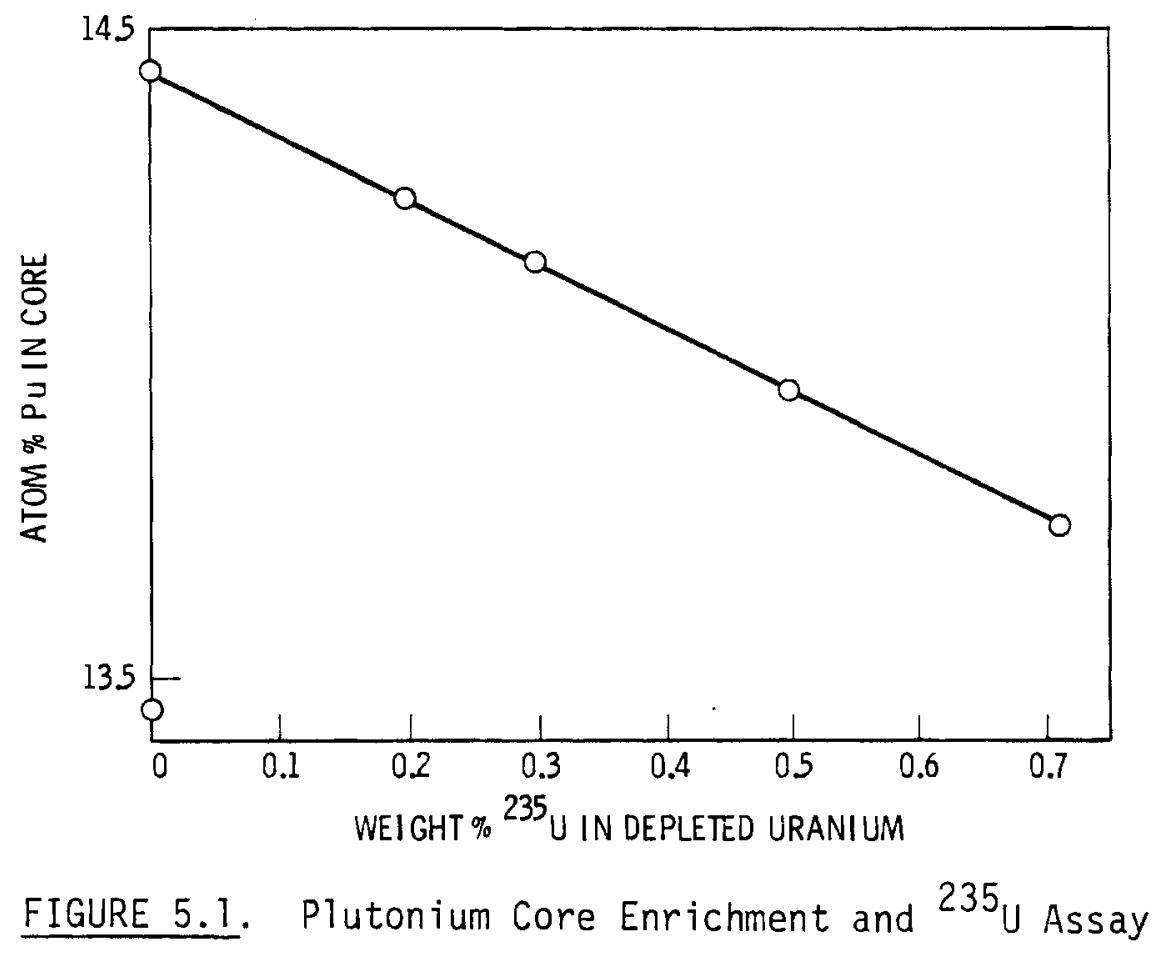

For each of the mass flow sets in Table 5.1 the fuel cycle cost can be evaluated as a function of depleted uranium feed and credit price. This relationsinip is expressed as:

$$
\text { Annual Fuel Cycle Cost }=F\left(T_{F}, T_{C}\right)
$$

where

$T_{F}$ is the Tails feed price, $\$ / \mathrm{kg} U$.

$T_{C}$ is the Tails credit price, $\$ / \mathrm{kg} U$.

Since the value of tails is derived from both the ${ }^{235} U$ and ${ }^{238} U$ content, a relationship for value as a function of assay can be postulated as:

$$
T(\$ / k g U)=a+b A
$$

where

$A$ is the ${ }^{235} U$ assay $w t \%$, and $a$ and $b$ are constants to be determined. 
A boundary condition for equation (6) is the market price of natural uranium (as ${U F_{6}}_{6}$ ), which is currently $\$ 118 / \mathrm{kg} U$. Substituting this into equation (6) yields:

$$
118=a+0.711 b
$$

To determine $a$ and $b$ the fuel cycle costs for the mass flows in Table 5.1 were evaluated. In these evaluations, the tails prices were expressed in form of equation (6) to arrive at a set of equations for fuel cycle costs expressed as functions of $a$ and $b$. Equating fuel cycle costs for any two sets of mass flows derives an indifference expression such that the power costs are equal utilizing either tails assay. These indifference equations, now expressed in terms of $a$ and $b$, together with boundary condition equation (7), allow a unique solution for $a$ and $b$. The intermediate steps for this process are given in Tables A.7 through A.9 in the Appendix. The results of a 11 combinations of tails assay considered are shown in Table 5.2.

TABLE 5.2. Calculated Coefficients for $a$ and $b$ in the Equation " $T(\$ / \mathrm{kg})=a+b A "$

\begin{tabular}{|c|c|c|}
\hline Data Combination & a & $\mathrm{b}$ \\
\hline $0.0 \mathrm{wt} \%$ and Natura 1 & 47.95 & 98.52 \\
\hline $0.0 w t \%$ and $0.5 w t \%$ & 48.66 & 97.52 \\
\hline $0.0 w t \%$ and $0.3 w t \%$ & 51.92 & 92.93 \\
\hline $0.0 \mathrm{wt} \%$ and $0.2 \mathrm{wt} \%$ & 48.61 & 97.59 \\
\hline $0.2 \mathrm{wt} \%$ and Natura 1 & 47.70 & 98.87 \\
\hline $0.2 w t \%$ and $0.5 w t \%$ & 48.69 & 97.48 \\
\hline $0.2 w t \%$ and $0.3 w t \%$ & 58.59 & 83.56 \\
\hline $0.3 \mathrm{wt} \%$ and Natura 1 & 45.07 & 102.58 \\
\hline $0.3 w t \%$ and $0.5 w t \%$ & 43.78 & 104.39 \\
\hline $0.5 \mathrm{wt} \%$ and Natura 7 & 46.29 & 100.86 \\
\hline Mean & 48.72 & 97.43 \\
\hline Standard Deviation & 4.12 & 5.80 \\
\hline
\end{tabular}


Averaging the calculated values for $a$ and $b$, gives a depleted uranium price equation of:

$$
\text { Tails Price }(\$ / \mathrm{kg} \mathrm{U})=49+97 \mathrm{~A}
$$

where

$$
A \text { is } 235 U \text { assay in } w t \% 235 U \text {. }
$$

Therefore, this ana?ys is results in a range of $\$ 49 / \mathrm{kg}$ to $118 \$ / \mathrm{kg} \mathrm{U}$ for the value of depleted uranium with $235 \mathrm{U}$ assay ranging from $0.0 \mathrm{wt} \% 235 \mathrm{U}$ to $0.711 \mathrm{wt} \%$ 235 . 


\subsection{VALUATION COMPARED TO ALTERNATIVE FERTILE MATERIAL-THORIUM}

In the previous section the use of depleted uranium as fertile material in LMFBRs was described. Other designs have also been proposed using thorium as the fertile blanket material. In these systems neutrons absorbed in the thorium produce ${ }^{233} \mathrm{U}$.

The comparison of fuel cycle costs using depleted uranium and thorium for fertile material allows the relative values of thorium and depleted uranium to be determined. Tables 6.1 and 6.2 display the steady state mass flows for two representative mixed oxide LMFBR designs. Both systems use mixed oxide cores and depleted uranium for the axial blanket. One system uses thorium for the radial blanket and the other uses depleted uranium. The Appendix contains the reactor characteristics and data used for this analysis.

Note that the core and axial blanket mass flows are almost identical. From this data it can be inferred that the majority of fuel cycle cost variation in these two systems will be in radial blanket performance. For each of these systems the annual fuel cycle costs can be expressed as the following functional relationship:

$$
\text { Annual Fuel Cycle Costs }(\$ / \text { year })=F(T, P, T h, U)
$$

where

$T$ is the depleted uranium price in $\$ / \mathrm{kg} \mathrm{U}$

$\mathrm{P}$ is the plutonium (core charge) price in $\$ / \mathrm{kg} \mathrm{Pu}$

Th is the thorium price in $\$ / \mathrm{kg}$ Th

$U$ is the ${ }^{233} \mathrm{U}$ price in $\$ / \mathrm{kg} \mathrm{U}$.

By choosing representative values for fuel cycle lead times, fabrication and reprocessing costs, and discount factor, equation (9) can be evaluated for both the depleted uranium and thorium radial blanket systems. Details of these calculations appear in the Appendix.

By equating these two functions, which represent the uranium and thorium fuel cycle power costs, and solving for $T$, the depleted uranium price, an 
TABLE 6.1. Steady State Mass Flows for Depleted Uranium Radia 7 Blanket Design, $\mathrm{kg} \mathrm{HM/Year}$

\begin{tabular}{|c|c|c|c|c|c|}
\hline \multirow[b]{2}{*}{ Component } & \multirow[b]{2}{*}{ Isotope } & \multicolumn{2}{|c|}{ _C Core __. } & \multirow[b]{2}{*}{ Axial Blanket } & \multirow[b]{2}{*}{ Radial Blanket } \\
\hline & & Zone 1 & Zone 2 & & \\
\hline \multirow{9}{*}{ Annual Charge } & $T h-232$ & -. & - & -. & -- \\
\hline & $U-233$ & -- & .. & -. & -. \\
\hline & $U-235$ & 23 & 22 & 31 & 22 \\
\hline & $U-238$ & 7965 & 7611 & 10240 & 7376 \\
\hline & Pu-239 & $66 i$ & 866 & -- & - \\
\hline & Pu-240 & 289 & 378 & -- & -- \\
\hline & $P_{u-241}$ & 138 & 179 & $\cdots$ & -. \\
\hline & Pu-242 & 37 & 48 & -. & -- \\
\hline & Totals & 2113 & 9104 & 10277 & 7408 \\
\hline \multirow{9}{*}{ Annual Discharge } & Th-232 & $\cdots$ & -- & .. & -- \\
\hline & $U-233$ & -- & .. & -- & -- \\
\hline & $U-235$ & 11 & 13 & 26 & 16 \\
\hline & $U-238$ & 7217 & 7109 & 10026 & 7146 \\
\hline & $P u-239$ & 806 & 982 & 188 & 199 \\
\hline & $P u-240$ & 329 & 401 & 5 & 11 \\
\hline & Pu-241 & 84 & 119 & -. & -- \\
\hline & $P u-242$ & 44 & 55 & -. & -- \\
\hline & Totals & 8491 & 8579 & 10245 & 7372 \\
\hline
\end{tabular}

TABLE 6.2. Steady State Mass Flows Thorium Blanket Design, \$/kg-HM Design, kg HM/Year

\begin{tabular}{|c|c|c|c|c|c|}
\hline \multirow{2}{*}{ Component } & \multirow[b]{2}{*}{ Isotope } & \multicolumn{2}{|c|}{-COre } & \multirow[b]{2}{*}{ Axial Slanket } & \multirow[b]{2}{*}{ Radial Blanket } \\
\hline & & Zone 1 & Zone $\hat{\varepsilon}$ & & \\
\hline \multirow{9}{*}{ Annual Charge } & $T h-232$ & -- & -. & -. & 6637 \\
\hline & $u-233$ & -- & - & $-\cdot$ & -- \\
\hline & $1 J-235$ & 24 & 23 & 31 & -. \\
\hline & $\mathrm{J}-238$ & 7963 & 7607 & 10244 & - \\
\hline & Pu-239 & 563 & 867 &.- & -- \\
\hline & Pu-240 & 289 & 379 & -- & -- \\
\hline & Pu-241 & 138 & 179 & -- & -- \\
\hline & Pu-242 & 36 & 47 & -. & -- \\
\hline & Tota1s & 9077 & 3102 & 10275 & 6637 \\
\hline \multirow{9}{*}{$\begin{array}{c}\text { Annual Dis- } \\
\text { charge }\end{array}$} & Th-232 & -- & 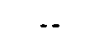 & -- & 6440 \\
\hline & $4-23.3$ & -- & -- & .. & 180 \\
\hline & $u-235$ & 11 & 14 & 26 & -- \\
\hline & $U-238$ & 7193 & 7117 & 10024 & $-\cdots$ \\
\hline & $P_{u-239}$ & 809 & 882 & 190 & -- \\
\hline & $P_{u-240}$ & 330 & 401 & 5 & -- \\
\hline & Pu-241 & 33 & 120 & -- & -- \\
\hline & $\mathrm{Pu}-242$ & 44 & 54 & -- & - \\
\hline & Totals & 8470 & 8588 & 10245 & 5620 \\
\hline
\end{tabular}


expression is obtained for $T$ as a function of other material prices. Using the mass flows on Tables 6.1 and 6.2 and cost data from the Appendix yields the expression:

$$
T(\$ / k g)=-23+0.935 T h+0.0510 P-0.026 U
$$

Equation (10) yields the price for depleted uranium that will give the two LMFBR systems analyzed the same fuel cycle costs.

Conclusions can be drawn from Equation (10) without obtaining precise values for Th, P and U. Equation (10) can be reformulated to isolate the tails and thorium price variables. This is expressed by:

$$
T-0.935 \text { Th }=-23+0.051 P-0.026 U
$$

If the right-hand side of Equation (11) is much greater than zero when a maximum value of $P$ and a minimum value of $U$ are assumed, it may be concluded that:

$$
\begin{aligned}
& T>0.935 \mathrm{Th} \text {, or } \\
& T>\text { Th }
\end{aligned}
$$

If the right-hand side of Equation (11) is much greater than zero for the maximum value of $P$ and the minimum value of $U$, then it will be much greater than zero for all possible values of these variables, and the conclusion that depleted uranium is always more valuable than thorium will be justified.

In a synergistic LWR-LMFBR economy, plutonium is more valuable to the LMFBR operator than to the operators of LWRs. The minimum value for plutonium in such an economy is calculated by comparing its use to low-enriched uranium in a LWR. The minimum value for plutonium is the value such that the LWR operator is indifferent to operating a LWR on the plutonium (MOX) fuel cycle or on the low-enriched uranium cycle. Tables A. 3 through A. 6 in the Appendix summarize this fuel cycle cost comparison. For the assumed scenario the minimum value of plutonium (as fed to the LMFBR or LWR) is $\$ 16.80 / \mathrm{g}$.

In a similar manner, the maximum value of ${ }^{233} \mathrm{U}$ can be calculated. Its value is a maximum when it is used in a LWR. Again, Tables A.3 through A.6 in the Appendix report the details of this analysis. For the scenario considered, the maximum value of $233 U$ is $\$ 24.40 / \mathrm{g}$. 
Subsituting these values into the right-hand side of Equation (11) yields

$$
\begin{aligned}
& -23+0.0510(16800)-0.26(24400)>>0 \text {, or } \\
& 245>0
\end{aligned}
$$

Since the relationship is satisfied with the minimum value $P$ and the maximum value of $U$, the conclusion that depleted uranium is more valuable than thorium is valid. Thus, the lower bound for the tails price is the value of thorium. Recent work has reported a range for thorium unit costs of 5 to $25 \$ / 1 \mathrm{~b} \mathrm{ThO}{ }_{2} \cdot{ }^{(5)}$ A value of $\$ 15 / 1 \mathrm{~b} \mathrm{\textrm {ThO } _ { 2 }}$ is representative. 


\subsection{REFERENCES}

1. Wall Street Journal, November 17, 1978.

2. D. R. Haffner et. al., Reactor Physics Parameters of Alternative Fueled FBR Core Designs. TC-947, Hanford Engineering Development Laboratory, Richland, WA, August 1977.

3. R. W. Hardie and W. W. Little, Jr., 1DX, A One-Dimensional Diffusion Code for Generating Effective Nuclear Cross Sections. BNWL-954, Pacific Northwest Laboratory, Richland, WA, 1969.

4. W. W. Little, Jr., and R. W. Hardie, 2DB User's Manual-Revision 1. BNWL 831 REV1, Pacific Northwest Laboratory, Richland, WA, 1969.

5. AFCT/TFCT/ISFS Program-Technical Progress Report for the Period January 1, 1978 - March 31, 1978. BNWL-2080-8, Pacific Northwest Laboratory, Richland, WA, 1978.

6. A. R. 01sen et. a1., Fuel Cycle Cost Studies-Fabrication, Reprocessing, and Fabrication of LWR, SSCR, HWR, LMFER, and HTGR Fuels. ORNL-TM-6522, Oak Ridge National Laboratory, Oak Ridge, TN, September 1978. 


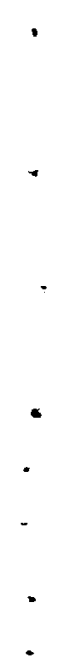




\section{APPENDIX}

Data in this appendix are supplementary to Sections 5.0 and 6.0. This appendix is intended to summarize the analysis and list key data and assumptions.

Applicable LMFBR and LWR system characteristics are shown in Tables A.1 and A.2. Assumed fuel cycle logistics and applicable unit costs are listed in Tables A.3 and A.4. Using the data listed in Tables A.1 through A.4, LWR annual fuel cycle costs can be calculated. These costs are shown in Table A.5 as a function of materials (natural uranium, plutonium, and ${ }^{233} \mathrm{U}$ ) price. Table A.6 lists fissile material indifference prices derived from data in Tables A.1 through A.5. Tables A.7 through A. 9 display the intermediate steps in deriving a functional relationship between tails price and ${ }^{235} U$ assay. The comparison of thorium and depleted uranium as they perform in an LMFBR radial blanket is summarized in Tables A.10 through A.13. 
TABLE A.1. LMFBR Design Parameters

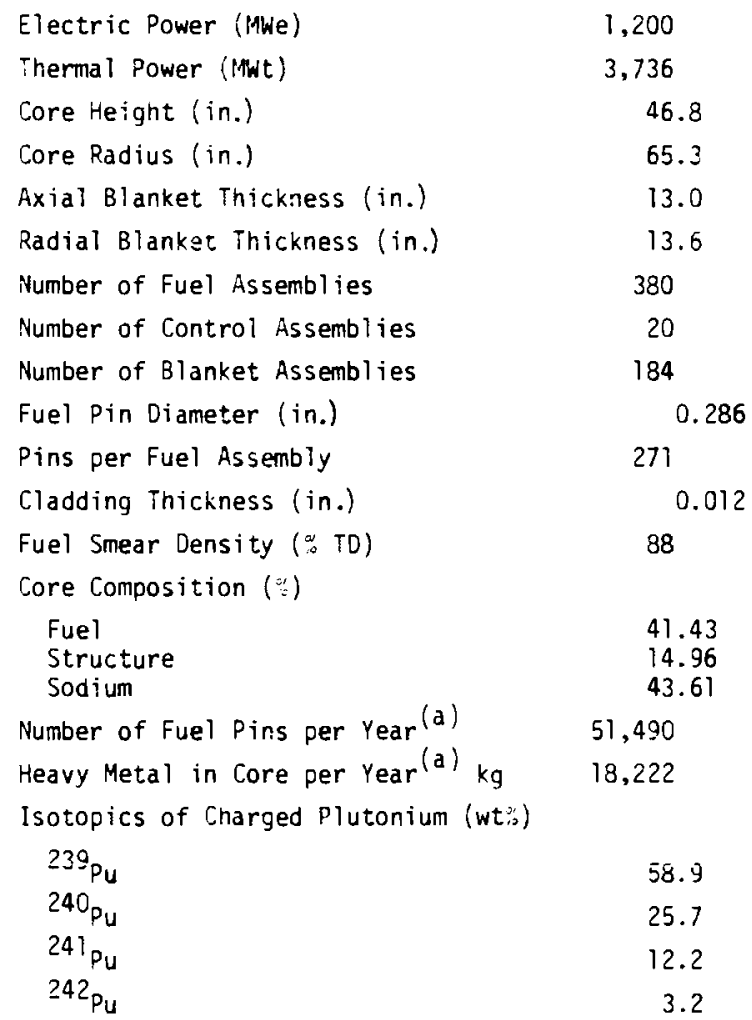

(a) 315 Full Power Days

\section{TABLE A.2. LWR Design Parameters}

$\begin{array}{lc}\text { Electric Power (MWe) } & 1105 \\ \text { Thermal Power (MWt) } & 3400 \\ \text { Core Height (in.) } & 144 \\ \text { Core Radius (in.) } & 66.4 \\ \text { Number of Fuel Assemblies } & 193 \\ \text { Fuel Pin Diameter. (in.) } & 0.374 \\ \text { Cladding Thickness (in.) } & 0.0225 \\ \text { Fraction of Core Discharged } & \\ \text { Annually } & 0.333 \\ \text { Heavy Metal Discharged } & \\ \text { Annually (MT) } & 28.9 \\ \text { 235U Enrichment, Steady } & \\ \text { State (wt\%) }\end{array}$




\section{TABLE A.3. Fuel Cycle Logistics Data}

\begin{tabular}{|c|c|c|}
\hline Parameter & Value & Comsment \\
\hline Discount Factor & 0.10 & $\begin{array}{l}\text { Representative utility value } \\
\text { for weighted cost of capital }\end{array}$ \\
\hline LWR Raw Materials Purchase ${ }^{(a)}$ & -1.00 & $\mathrm{U}_{3} \mathrm{O}_{8}$, MOX, or ${ }^{233} \mathrm{U}$ as appropriate \\
\hline LWR Conversion & -0.75 & Not appropriate for $M O x$ or $233_{U}$ \\
\hline LWR Enrichment & -0.50 & Not appropriate for MOx or ${ }^{233} \mathrm{U}$ \\
\hline LWR Fabrication & -0.25 & -- \\
\hline LWR Exposure Period & 3.00 & -- \\
\hline LWR Reprocessing & 4.00 & $-\cdots$ \\
\hline LWR Materials Credit & 4.00 & Credit for recovery of $P u, U$, etc. \\
\hline LMFBR Raw Materials Purchase & -1.00 & Plutonium purchase \\
\hline LMFBR Fabrication & -0.50 & -- \\
\hline LMFBR Exposure Period (b) & 2.00 & -- \\
\hline LMFBR Reprocessing & 3.00 & -- \\
\hline LMFBR Materials Credit & 3.00 & Credit for recovery of $\mathrm{Pu}, \mathrm{U}$, etc. \\
\hline
\end{tabular}

(a) Fuel cycle timing values are reported in years relative to fuel loading at the reactor.

(b) Radial blanket exposure periods are 2 to 3 years longer.

TABLE A.4. Fuel Cycle Unit Costs (1978 Dollars) ${ }^{(a)}$

\begin{tabular}{|c|c|c|}
\hline Parameter & Unit Cost $\$ / \mathrm{kg} H M$ & Comment \\
\hline Natural $\mathrm{U}_{3} \mathrm{O}_{8}$ & 113 & $\begin{array}{l}\text { Current spot } \\
\text { price }\end{array}$ \\
\hline $\mathrm{ThO}_{2}$ & 38 & $\begin{array}{l}\text { Estimate based } \\
\text { on reference } 5\end{array}$ \\
\hline Conversion $\mathrm{U}_{3} \mathrm{O}_{8}+\mathrm{UF}_{6}$ & 5 & -- \\
\hline Enrichment & 86 per SWU & $\begin{array}{l}\text { Current ceiling } \\
\text { price }\end{array}$ \\
\hline LWR ${ }^{235} \mathrm{UO}_{2}$ Fabrication & 130 & -- \\
\hline LWR ${ }^{233} \mathrm{UO}_{2}$ Fabrication & 630 & -- \\
\hline LWR MOX Fabrication & 430 & -- \\
\hline $\begin{array}{l}\text { LMFBR Core and Axial Blanket } \\
\text { Fabrication }\end{array}$ & 650 & -- \\
\hline $\mathrm{UO}_{2}$ Radial Blanket Fabrication & 140 & -- \\
\hline $\mathrm{ThO}_{2}$ Radial Blanket Fabrication & 150 & -- \\
\hline LWR Fuel Reprocessing & 230 & -- \\
\hline LMFBR Fuel Reprocessing & 230 & -- \\
\hline Waste Management & 150 & $\begin{array}{l}\text { Applicable at } \\
\text { reprocessing }\end{array}$ \\
\hline Transportation & 30 & -- \\
\hline
\end{tabular}

(a) All fabrication and reprocessing datz are taken from Reference 6 . 
TABLE A.5. LWR Fuel Cycle costs

\begin{tabular}{|c|c|}
\hline System & Annual Fuel Eycle Costs ( 5 millions) \\
\hline Low Enriched Uranium & $23.25+0.1742 \mathrm{NU}-0.0001877 \mathrm{P}$ \\
\hline Mixed $0 x$ ide & $19.98+0.03032 \mathrm{NU}+0.0009736 \mathrm{P}$ \\
\hline $233 \mathrm{U}$ in Natural Uranium & $25.91+0.03124 N U-0.0001837 P+0.0005523 U 3$ \\
\hline${ }^{233} \mathrm{U}$ in Thorium & $26.94+0.01224 \mathrm{Th}+0.0005539 \mathrm{U} 3$ \\
\hline
\end{tabular}

where:

NU, Natural uranium price, $\$ / \mathrm{kg} U$

$P$, LEU discharge plutonium price, $\$ / \mathrm{kg} r M$

Th, Thorium price, $\$ / \mathrm{kg}$ Th

U3, $233 \mathrm{U}$ price, $\$ / \mathrm{kg}$ IJ

TABLE A.6. LWR Fissile Material Indifference Prices for Natural Uranium at $\$ 113 / \mathrm{kg}$ U(a)

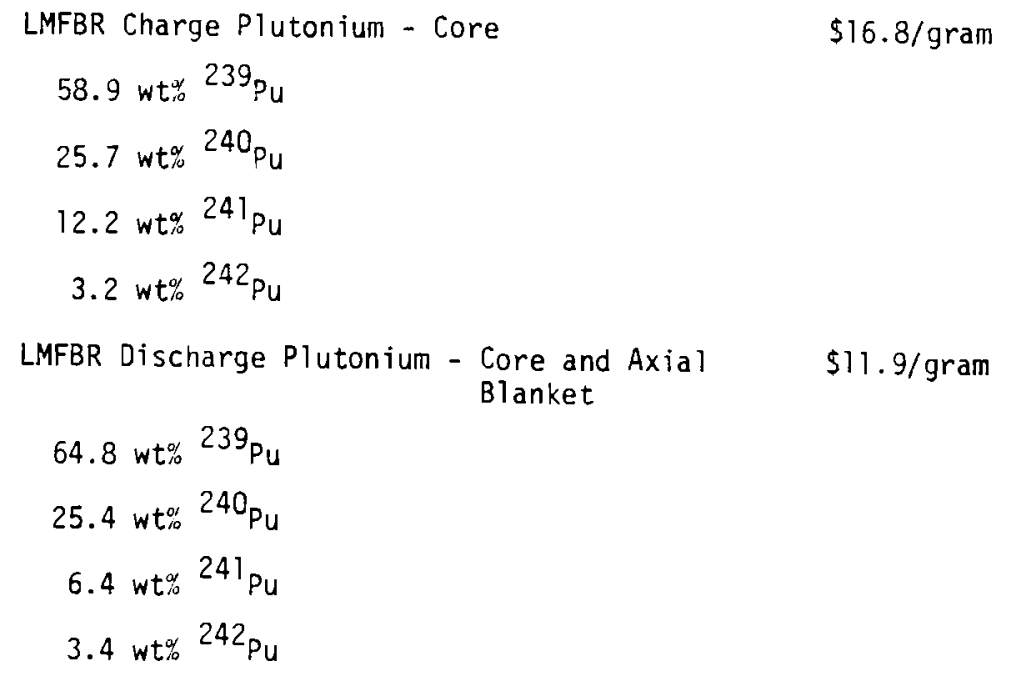

LMFBR Discharge Plutonium - Depleted Uranium \$27.8/gram 94.8 wt\% $239 \mathrm{Pu}$

$5.2 \mathrm{wt}_{\%}^{\circ} 240 \mathrm{Pu}$

$<.1 \mathrm{wt} \%{ }^{241} \mathrm{Pu}$

LMFBR Discharge 233 - Thorium Radial Blanket $\$ 24.4 /$ gram

(a) At these price jevels the LWR operator is indifferent to operating with $235 \mathrm{U}$ enriched uranium (for the systems summarized in Table A.2 and A.3) or purchasing the above fissile materials. The power costs are identical. 


\section{TABLE A.7. LMFBR Fuel Cycle costs as a Function of Tails Assay}

Tails Feed Assay, wt; ${ }^{235} \mathrm{U}$

0.0
0.2
0.3
0.5
0.711 (Narai)

Fuel Cycle Costs, Discounted 1978 Dollars (\$ millions)

$$
\begin{aligned}
& 50.7889+0.014676 \mathrm{~T}(0.0)^{(a)} \\
& 50.3596+0.038652 \mathrm{~T}(0.2)-0.018331 \mathrm{~T} \\
& (0.1367)-0.0056231 \mathrm{~T}(.1670) \\
& 50.1810+0.038672+(0.3)-0.018341 \mathrm{~T} \\
& (0.2097)-0.0056235 \mathrm{~T}(0.2513) \\
& 49.7324+0.038712 \mathrm{~T}(0.5)-0.018360 \mathrm{~T} \\
& (0.3429)-0.0056211 \mathrm{~T}(0.4193) \\
& 49.2738+0.038751(0.711)-0.018380 \mathrm{~T} \\
& (0.488)-0.0056179 \mathrm{~T}(0.595)
\end{aligned}
$$

(a) $\Gamma(0.0)$ is the value of depleted uranium at a $235 \mathrm{U}$ assay of $0.0 \mathrm{wt}$.

\section{TABLE A.8. LMFBR Fuel Cycle Costs as a Function of "a" and "b" $(a)$}

Tails Feed Assay, wt., $235_{U}$

$$
0.0
$$

0.2

0.3

0.5

0.711 (Natural)
Fuel Cycle Costs, Discounted 1978 Dollars (S millions)
$50.7889+0.014676 a$
$50.3596+0.014698 a+0.00428549 b$
$50.1810+0.014708 a+0.00641571 b$
$49.7324+0.0147309 a+0.0107034 b$
$49.2738+0.0147531 a+0.0152340 b$

(a) This table is derived from Table A.7 by formulating the tails price as $T=a+b A$ where $A$ is the $235 \mathrm{U}$ assay. 


\section{TABLE A.9. Indifference cost Equation as a}

Function of "a" and "b"

\begin{tabular}{|c|c|c|c|}
\hline \multirow[b]{2}{*}{ Data Combination } & \multirow[b]{2}{*}{ Equation } & \multicolumn{2}{|c|}{ Solution $^{(a)}$} \\
\hline & & $a$ & $b$ \\
\hline $0.0 w_{\%}^{\circ}$ and Natural & $1.5051=7.71 \mathrm{E}-5 \mathrm{a}+0.015240$ & 47.95 & 98.52 \\
\hline $0.0 \mathrm{wt}_{\%}^{\mathrm{o}}$ and $0.5 \mathrm{wt}^{\circ}$ & $1.0464-5.49 E-5 a+0.010703$ & 48.66 & 97.52 \\
\hline $0.0 w t^{\%}$ and $0.3 w t_{\%}^{o \%}$ & $0.5979=3.20 \mathrm{E}-5 \mathrm{a}+0.0064157$ & 51.92 & 92.93 \\
\hline $0.0 w t \%$ and $0.2 w t \%$ & $0.4193=2.00 E-5 a+0.0042855$ & 48.61 & 97.59 \\
\hline $0.2 w t^{\%}$ and Natural & $1.0858=5.31 \mathrm{E}-5 \mathrm{a}+0.010955$ & 47.70 & 98.87 \\
\hline $0.2 w t \%$ and $0.5 w_{t}^{\alpha} \%$ & $0.6272=3.29 \mathrm{E}-5 \mathrm{a}+0.0064179$ & 48.69 & 97.48 \\
\hline $0.2 w t \%$ and $0.3 w t \%$ & $0.1786=1.00 \mathrm{E}-5 \mathrm{a}+0.0021303$ & 58.59 & 83.56 \\
\hline $0.3 w t \%$ and Natural & $0.0972=4.51 \mathrm{E}-5 \mathrm{a}+0.0088243$ & 45.07 & 102.58 \\
\hline $0.3 w t \%$ and $0.5 w t^{\alpha}$ & $0.4486=2.29 E-5 a+0.0042877$ & 43.78 & 104.39 \\
\hline $0.5 w t \%$ and Natural & $0.4585=2.22 E-5 a+0.0045366$ & 46.29 & 100.86 \\
\hline
\end{tabular}

a) Obtained by the boundary condition at natural; $118=a+0.711 b$.

TABLE A.10. LMFBR Parameter Analysis - Annual Fuel Cycle Costs, Discounted 1978 Dollars (\$000)

\begin{tabular}{|c|c|c|c|c|}
\hline \multirow[b]{2}{*}{ Sensitivity Parameter ${ }^{(a)}$} & \multicolumn{2}{|c|}{ Depieted Urarıium Systemı } & \multicolumn{2}{|c|}{ Thorium System } \\
\hline & $\begin{array}{l}\text { Core and } \\
\text { Axial Blanket } \\
\end{array}$ & Radial Blanket & $\begin{array}{c}\text { Core and } \\
\text { Axial Blanket }\end{array}$ & Radial Blanket \\
\hline Zero Materials Value & 27101.87 & 2669.92 & 27220.48 & 2461.30 \\
\hline$=23 \mathrm{U}$ Credit & --- & $\cdots$ & -- & 2562.91 \\
\hline Th Feed & -- & $\cdots$ & -- & 9743.30 \\
\hline Th Credit & $\cdots$ & -- & $\cdots$ & 6096.51 \\
\hline Pu Feed & 29971.77 & -- & 30095.87 & --- \\
\hline Pu Credit & 29283.57 & 2788.46 & 29405.93 & $\cdots$ \\
\hline Tails Feed & 55391.67 & 10818.72 & 55701.68 & $\cdots$ \\
\hline Tails Credit & $45435.40 \hat{~}$ & 6712.68 & 45541.29 & --- \\
\hline
\end{tabular}

a) Sensitivites were evaluated by holding ali material feed costs and credits at zero except the parameter of interest. The parameter evaluated was set at $\$ 1000 / \mathrm{kg}$ to evaluate the effect on the system. 


\section{TABLE A.11. LMFBR Sensitivity Parameters}

Depleted Uranium System

\section{Sensitivity Parameter (a)}

Zero Materials Cost $(a)$

$233 \mathrm{U}$ Credit ${ }^{(b)}$

Th Feed

Th Credit

Pu Feed

Pu Credit

Tails Feed

Tails Credit
Core and

Axial Blanket

27101.37
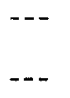

$--$

2.8699

2.1817

28.2898

18.3336

\section{Radial Blanket}

2669.92
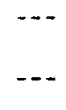

$-\cdots$

$-\cdot$

0.11854

8.1488

4.0428
Thorium System

Core and
Axial Blanket

27220.48

2461.30

$--$

0.10161

7.2820

3.6352

2.8754

2.1855

28.4812

18.3208
$-$.

$-\cdot$

$-\cdot-$

a) This value is the base fuel cycle costs in thousands of dollars for zero materials cost.

b) Parameter units are $\frac{\$ 1000 ' \mathrm{~s}}{\$ / \mathrm{kg}}$.

TABLE A.12. LMFBR Annual Fuel Cycle cost Equations

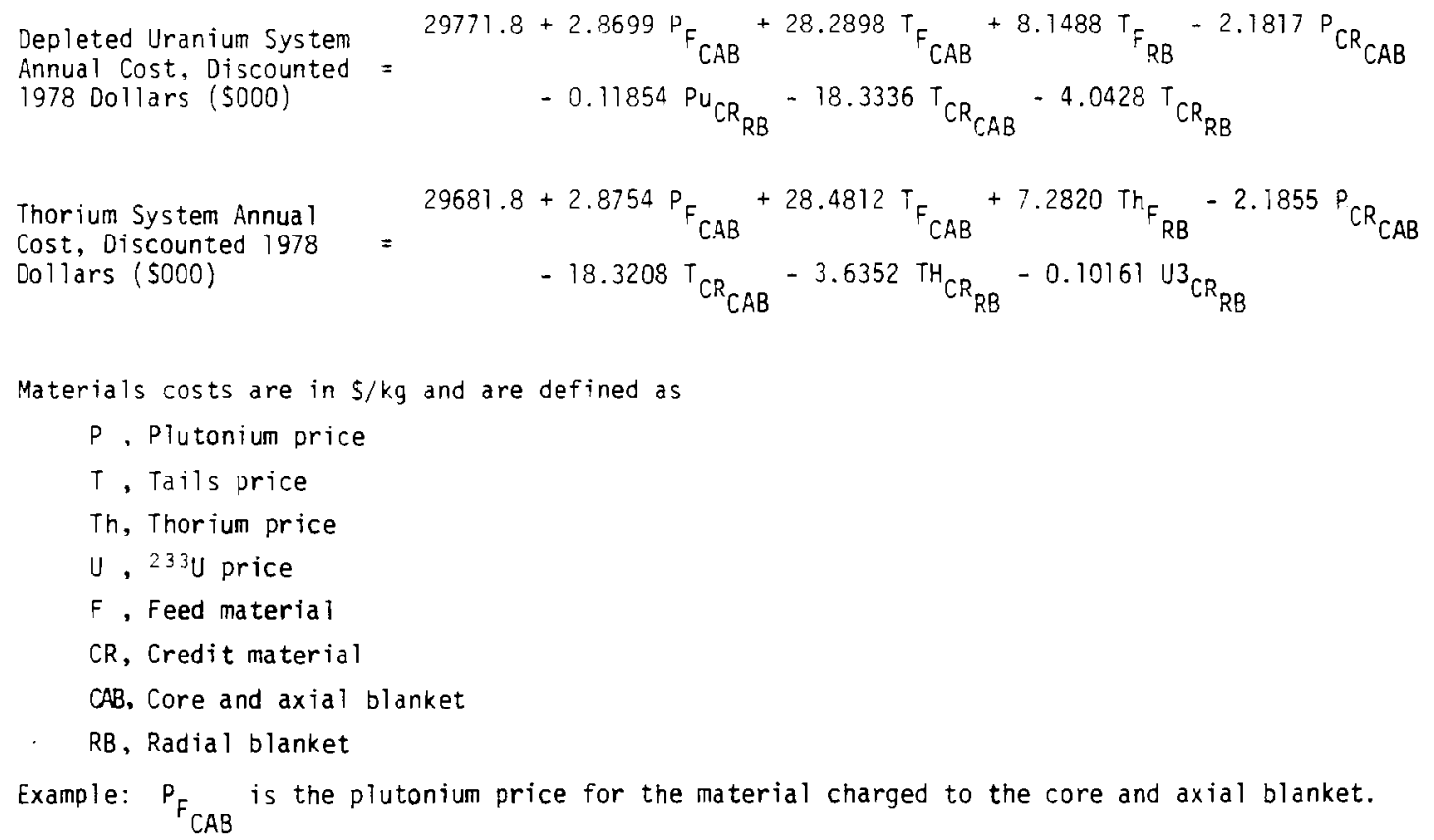


TABLE A.13. LIMFBR Tails Valuation - Comparison With Thorium

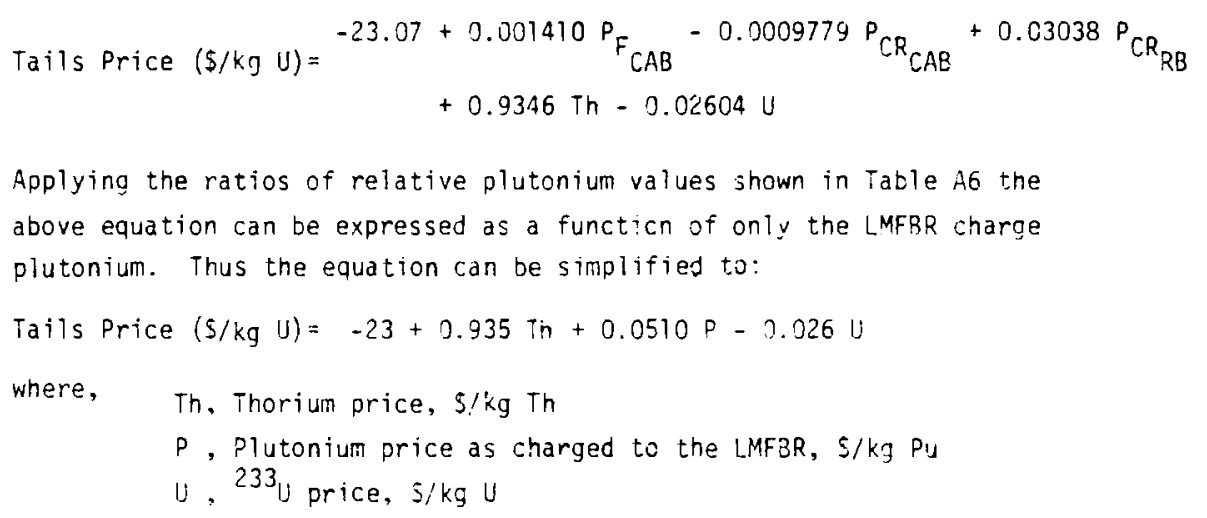


No. of

Copies

OFFSITE

A. A. Churm

DOE Patent Division

9800 South Cass Avenue

Argonne, IL 60439

27 DOE Technical Information Center

W. W. Ballard

Department of Energy

Washington, DC 20545

R. W. Gagne

Department of Energy

Washington, JC 20545

E. E. Rutkowski

Department of Energy

Washington, DC 20545

\section{ONSITE}

1 DOE Richland Operations Office

H. E. Ransom

29 Pacific Northwest Laboratory

A. J. Boegel

C. M. Heeb

R. M. Fleischman

U. P. Jenquin

M. A. Lewallen (10)

R. C. Liikala

E. T. Merrill

D. F. Newman

M. K. White (5)

L. D. Williams

Technical Information Files (5)

Publishing Coordination (2) 
.

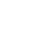

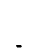

